\title{
“Tão natural"
}

in casadasciencias.org/banco-imagens

\section{CITAÇÃO}

Fernandes, P. A. \& Félix, F. F.(2021)

"Tão natural",

Rev. Ciência Elem., V9(04):072.

doi.org/10.24927/rce2021.072

\section{EDITOR}

João Nuno Tavares

Universidade do Porto

\section{EDITOR CONVIDADO}

Maria João Ramos

Universidade do Porto

\section{RECEBIDO EM}

26 de novembro de 2021

\section{ACEITE EM}

26 de novembro de 2021

\section{PUBLICADO EM}

15 de dezembro de 2021

\section{COPYRIGHT}

(C) Casa das Ciências 2021.

Este artigo é de acesso livre, distribuído sob licença Creative Commons com a designação CC-BY-NC-SA 4.0, que permite a utilização e a partilha para fins não comerciais, desde que citado o autor e a fonte original do artigo.
A imagem de uma formação geológica do período do Jurássico Superior (163 - 145 milhões de anos atrás), de Francisco Félix, faz-nos vislumbrar a pele retorcida e couraçada que imaginamos em alguns dos habitantes desse período, fértil em dinossauros.

Faz-nos imaginar o duro couro de um qualquer dinossauro herbívoro, de entre a vasta lista que habitou a Terra nesse período e que nunca conheceremos completamente, couro esse que talvez o protegesse, pelo menos um pouco, dos ataques dos enormes carnívoros da época, tal como os alossauros, temíveis feras que habitavam o nosso país, cujo registo fóssil foi encontrado curiosamente próximo do local onde a formação geológica foi fotografada.

Pedro Alexandrino Fernandes DQB/ Universidade do Porto
A imagem transporta-me de imediato para um passeio efetuado na orla costeira do território abrangido pelo Aspirante Geoparque Oeste, durante umas férias de Natal. As interrupções letivas constituem momentos formativos de excelência, como por exemplo, o contacto direto com a base de arribas, neste caso, suportadas por materiais depositados no Jurássico Superior. Dado que alguns afloramentos se situam em locais de difícil acesso, a disponibilização de representações destas possibilitam a sua utilização em vários contextos didático-pedagógicos. A meu ver, a atratividade das figuras constitui um bom ponto de partida para aventuras ao nível do conhecimento científico. Neste caso, pode-se viajar pelo paleoambiente e percecionar os fluxos que permitiram a deposição dos detritos constituintes da rocha. Depois, explorar a diagénese e finalmente verificar os fatores que contribuíram para a exposição e morfologias evidenciadas. A fotografia foi captada próximo da linha de fronteira entre dois concelhos, cujo património geológico e paleontológico sobressaem na dinâmica dos georrecursos culturais - Peniche e Lourinhã.

Francisco Fidalgo Félix

Escola Secundária de Peniche

rce.casadasciencias.org






\section{REVISTA DE CIÊNCIA ELEMENTAR}

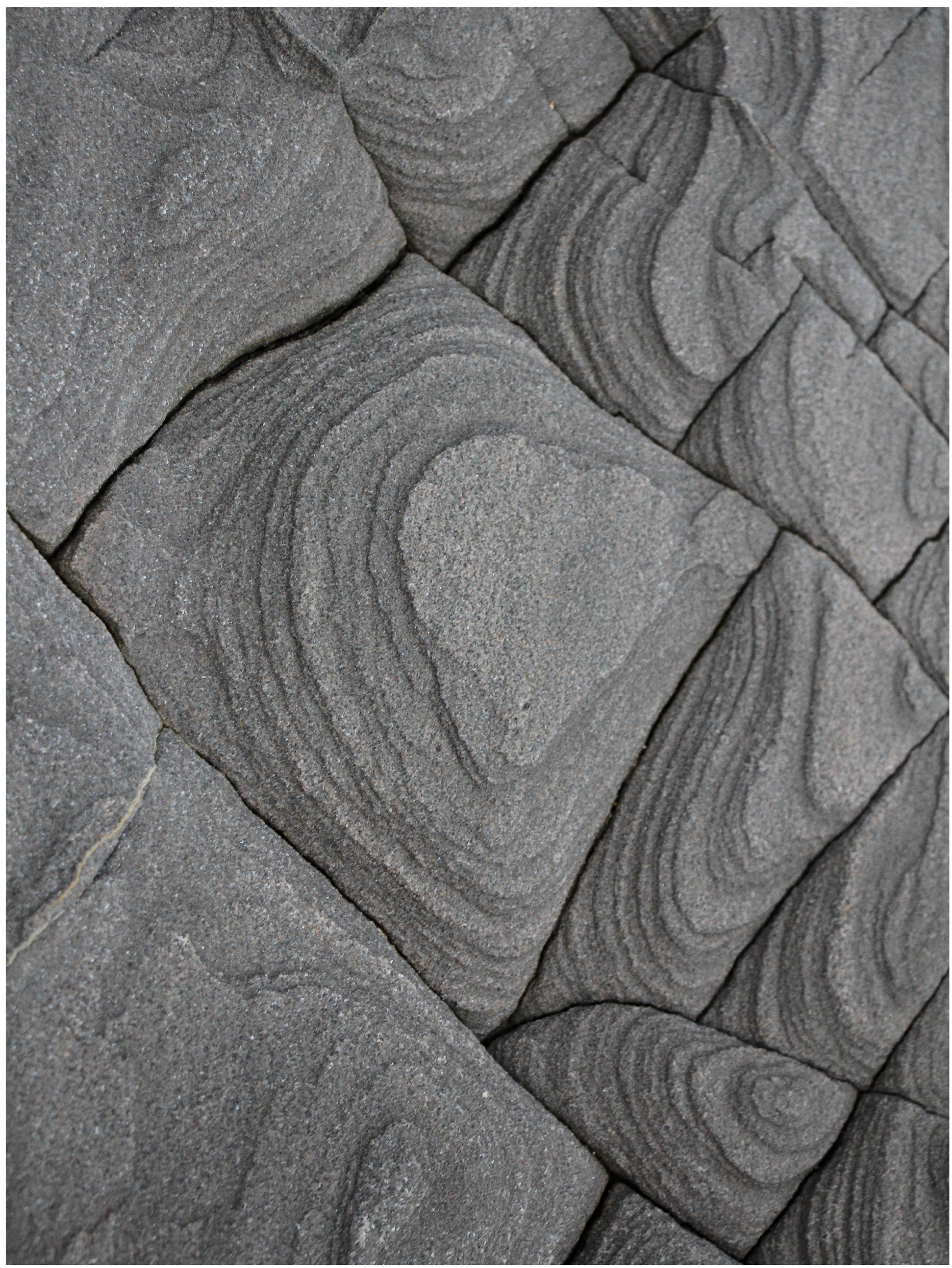

